\title{
CLASTIC SINKHOLE AND PSEUDOKARST DEVELOPMENT IN EAST TEXAS
}

\author{
Kevin W. Stafford, Melinda G. Shaw-Faulkner, Wesley A. Brown \\ Department of Geology, Stephen F. Austin State University, P.O. Box 13011, SFA Station, Nacogdoches, Texas, \\ 75962-3011,staffordk@sfasu.edu
}

\begin{abstract}
Pseudokarst development in East Texas is controlled primarily by a combination of suffosion and preferential flow paths, often creating small ephemeral sinkholes but occasionally persistent features develop in more indurated facies. Pseudokarst occurs in Claiborne (Eocene) strata in Angelina, Cherokee, Nacogdoches, Panola, Rusk, San Augustine and Shelby counties. Strata consist of interbedded fine- and coarse-grained clastics with variable cementation and associated permeabilities. Preferential fluid migration along fractures and bedding planes create local voids through suffosion that stope upward to create sinkholes and incised collapse valleys often associated with persistent and ephemeral springs.
\end{abstract}

GIS-based delineation of pseudokarst sinkholes is complicated in the region by low gradient fluvial systems and extensive anthropogenic overprinting regionally, which create numerous constructional closed depressions. Sinkhole densities coupled with slope analyses indicate clustered regions of pseudokarst development within Carrizo, Queen City and Sparta sandstones. Known pseudokarst caves within the region include features developed along low permeability boundaries where discharge interface features occur. Gunnels Cave is an end member product of natural suffosion processes in East Texas with more than 160 meters of surveyed passage and a collapse sinkhole covering approximately a hectare. Smaller suffosion sinkholes occur along steep gradients but generally remain associated with fracture-controlled flow paths, either forming bypass features or enlarged regions associated with spring discharge. Anthropogenic pseudokarst sinkholes are generally associated with leaky pipelines and focused groundwater recharge from impermeable surfaces and produce local geohazards. Traditionally East Texas is not known for extensive pseudokarst development; however, isolated caves and sinkholes can be locally significant and potential geohazards.

\section{Introduction}

Traditionally, East Texas has never been considered a dominant karst region because of the lack of soluble facies in near-surface environments. The region is dominated by Cenozoic clastic sediments associated with shallow marine, lagoonal, deltaic and fluvial deposition (Sellards et al., 1932). Mesozoic carbonate and evaporite strata in the region are deeply buried units that are heavily exploited for hydrocarbon resources (Nichols et al., 1968). These deeper strata inevitably host hypogene karst associated with hydrocarbon maturation and burial diagenesis; however, surficial Cenozoic strata are limited to pseudokarst development, where mechanical disaggregation of grains along focused flow paths creates void space.

Pseudokarst includes any geomorphic features that exhibit morphologies similar to true karst features but have not been formed from solutional processes (Palmer, 2007). Pseudokarst traditionally includes caves, sinkholes and springs but generally lacks karren development. In East Texas, these traditional characteristics have been documented as widespread occurrences, but never in dense concentrations (Atkinson, 2003); however, many small, ephemeral suffusion features commonly occur which act as bypass features for overland flow and direct recharge of shallow groundwater systems. Springs abound in the region as shallow, unconfined aquifer systems discharge along low permeability horizons and where semi-confined and confined aquifer systems discharge vertically to the land surface along preferential flow paths created by brittle deformation.

While pseudokarst development is relatively rare in East Texas compared to true karst development in other regions of the state (Elliot and Veni, 1994), these features do provide unique ecological and culture resources for the region. The Texas Speleological Survey officially reports that thirty seven pseudokarst caves and karst features exist in sixty one counties that cover the greater East Texas region (Atkinson, 2003). This study focuses 
on seven counties (Angelina, Cherokee, Nacogdoches, Panola, Rusk, San Augustine and Shelby) (Figure 1), where pseudokarst cave development is primarily limited to coarser grained, sandstone facies of the Claiborne Group (Figure 2), including the Carrizo, Queen City and Sparta formations, while springs and seeps can be found throughout all facies of the Wilcox, Claiborne and Jackson groups where permeability horizons intersect the land surface.

Wilcox Group strata form a heterogeneous series of sandy littoral clays, fluvial sands, lacustrine clays, lignite lentils and deltaic silts, with sand abundance increasing towards the top of the section (Sellards et al., 1932). The Claiborne Group is characterized by a rhythmic series of marine and continental sediment deposits as the Eocene strandline migrated in response to sea level fluctuations (Sellards et al., 1932) and is divided into seven formations (Figure 2) detailed below. Jackson Group strata consist of medium- to fine-grained sands forming thin beds mixed with argillaceous clays and lentils of coarse sands. Tuffaceous material derived from Eocene pyroclastic eruptions is common throughout the Jackson Group (Sellards et al., 1932).

Pseudokarst development in East Texas has only been documented in the Claiborne Group (Stafford et al.,

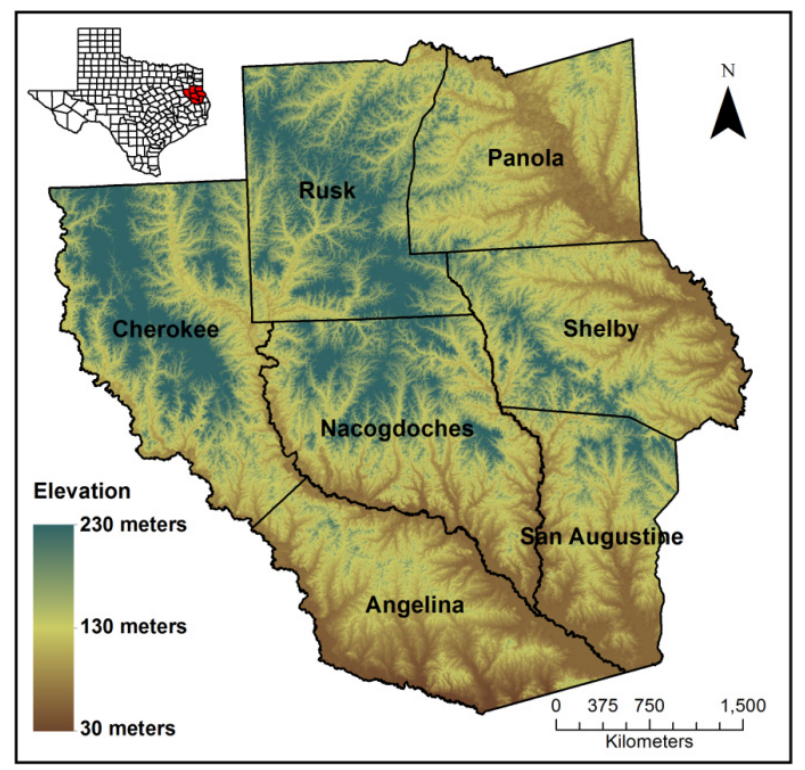

Figure 1. Digital elevation model of seven East Texas counties encompassing study area. Note the extensive drainage development associated with low gradient fluvial systems in East Texas clastic strata (data from Texas Natural Resources Information System).

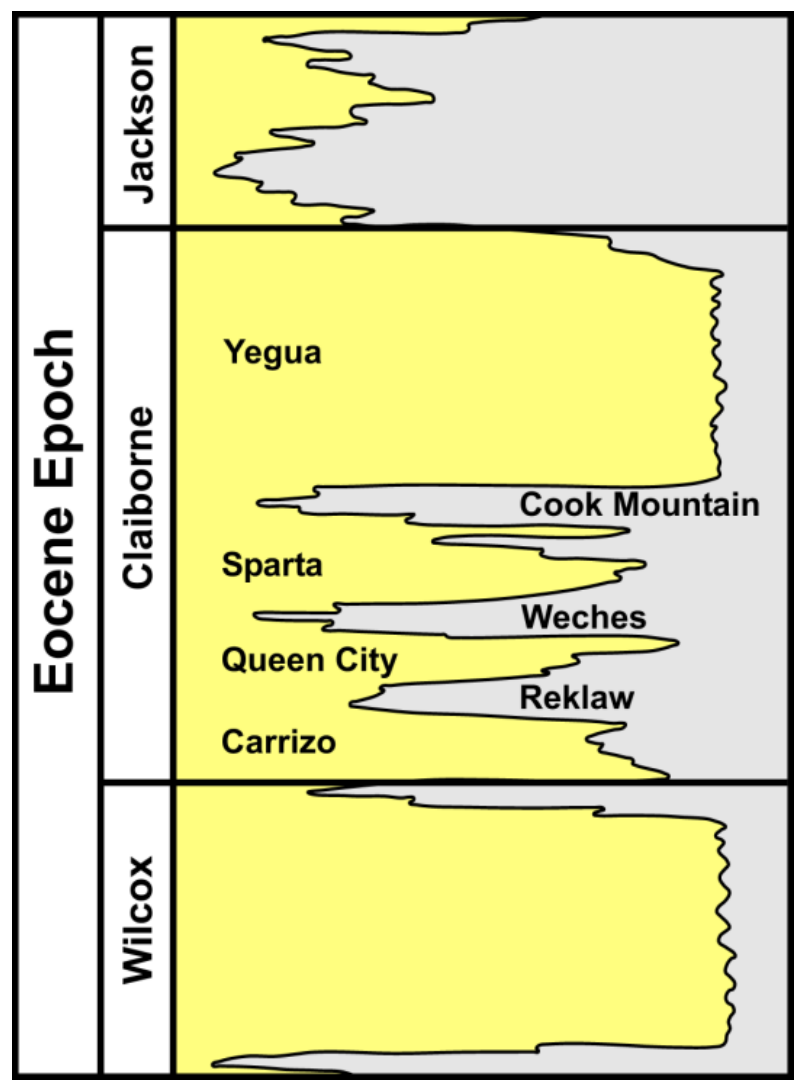

Figure 2. Simplified stratigraphic section of East Texas Eocene units. Yellow indicates relative abundance of sandstone dominate facies, while grey represents relative abundance of mudstone facies. Claiborne Group divided into formations.

2010), which consist of the Carrizo, Reklaw, Queen City, Weches, Sparta, Cook Mountain and Yegua formations, in ascending order (Shelby et al., 1968). Carrizo Sand is a massive, very fine- to fine-grained quartz sandstone that is locally cross-bedded and often carbonaceous or ferruginous. The Reklaw Formation is composed of heterogeneous fine- to medium-grained sandstone with abundant glauconitic clay. Queen City Sand is mediumto fine-grained quartz sand that is locally clay-rich and lignitic. The Weches Formation is primarily glauconitic sand with clay interbeds that is often lenticular with local ironstone concretions. Sparta Sand is a very fine - to finegrained massive sandstone that is locally carbonaceous and commonly contains interbeds of silty or sandy clay. The Cook Mountain Formation is primarily clay or marly sand, but locally grades into sheet clays and glauconitic sands. The Yegua Formation is dominated by clay with minor sandstone beds and local concretionary limestone beds; locally it is laminated and contains silicified tuff (Shelby et al., 1968). 
Angelina, Cherokee, Nacogdoches, Panola, Rusk, San Augustine and Shelby counties cover 15,146 km² within the Interior Coastal Plains (Wermund, 1996), with elevations ranging from 30 to $230 \mathrm{~m}$ asl (Figure 1). Climate in the region is subtropical humid with annual and monthly average precipitations of $1230 \mathrm{~mm}$ and 102 $\mathrm{mm}$, respectively (Estaville and Earl, 2008). Average precipitation increases slightly in late fall and spring with slight decreases in late summer. Temperature averages $19^{\circ} \mathrm{C}$, with an average annual lows and highs of $3^{\circ} \mathrm{C}$ and $35^{\circ} \mathrm{C}$, respectively in January and August (Estaville and Earl, 2008). The region is dominated by mixed pine and hardwood forests with numerous low gradient streams.

\section{East Texas Geology}

East Texas is dominated by the deposition of Cenozoic clastic sediments associated with the transgression and regression of coastal strandlines that deposited extensive fluvial, deltaic, lagoonal and shallow marine sediments (Sellards et al., 1932), including strata of the Wilcox, Claiborne and Jackson groups as well as overlying quaternary alluvium and terrace deposits (Figure 3). Structurally, the region is dominated by the Sabine Arch (Figure 4), a basement uplift formed during the late Mesozoic

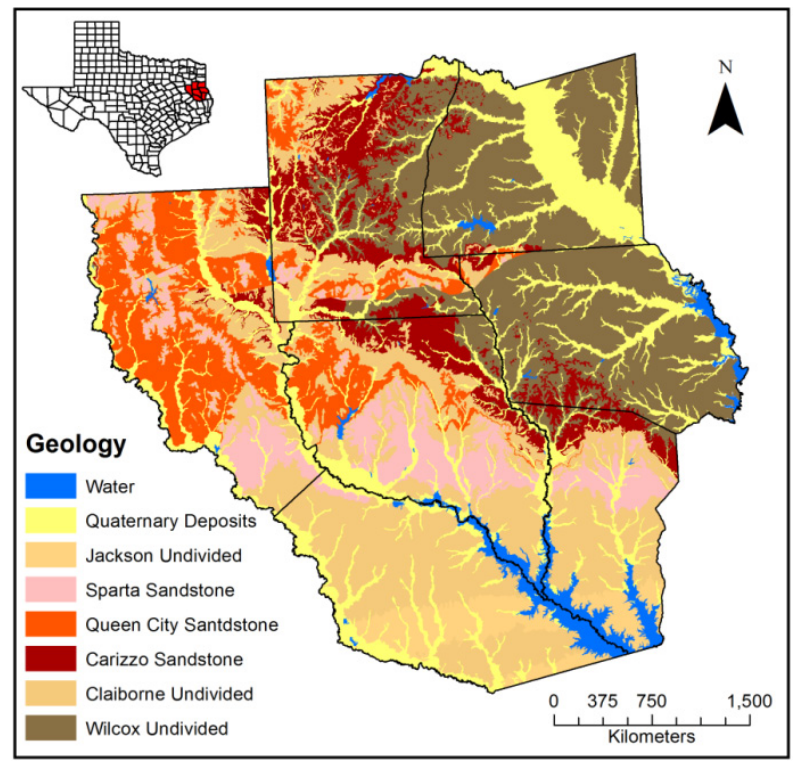

Figure 3. Simplified geologic map of East Texas study area, with Jackson and Wilcox Groups undivided. Cook Mountain, Reklaw, Yequa and Weches formations of the Claborne Group are undivided. Carizzo, Queen City and Sparta sandstones are presented in contrast because these formations are known to host pseudokarst development (data from Texas Natural Resources Information System). to early Cenozoic through buckling induced by the Saltillo-St. Lawrence shear system which created the large, low amplitude, anticlinal feature in East Texas and Louisiana (Adams, 1990). The Mexia-Talco Fault Zone borders the eastern and northern portions of East Texas with the Elkhart-Mt. Enterprise Fault Zone dissecting the study area (Figure 4), associated with the Ouachita tectonic front and the Saltillo-St. Lawrence shear system respectively (Adams, 1990). These fault systems have produced abundant near vertical fractures throughout the study area primarily oriented east/northeast, which provide preferential planes for fluid migration.

Stratigraphically the region is dominated by Eocene clastics (Figure 2). Wilcox strata are largely undifferentiated in the region because of heterogeneous fine- to medium-grained sandstones, lacustrine clays, and lignite lenses, with total thicknesses exceeding 500

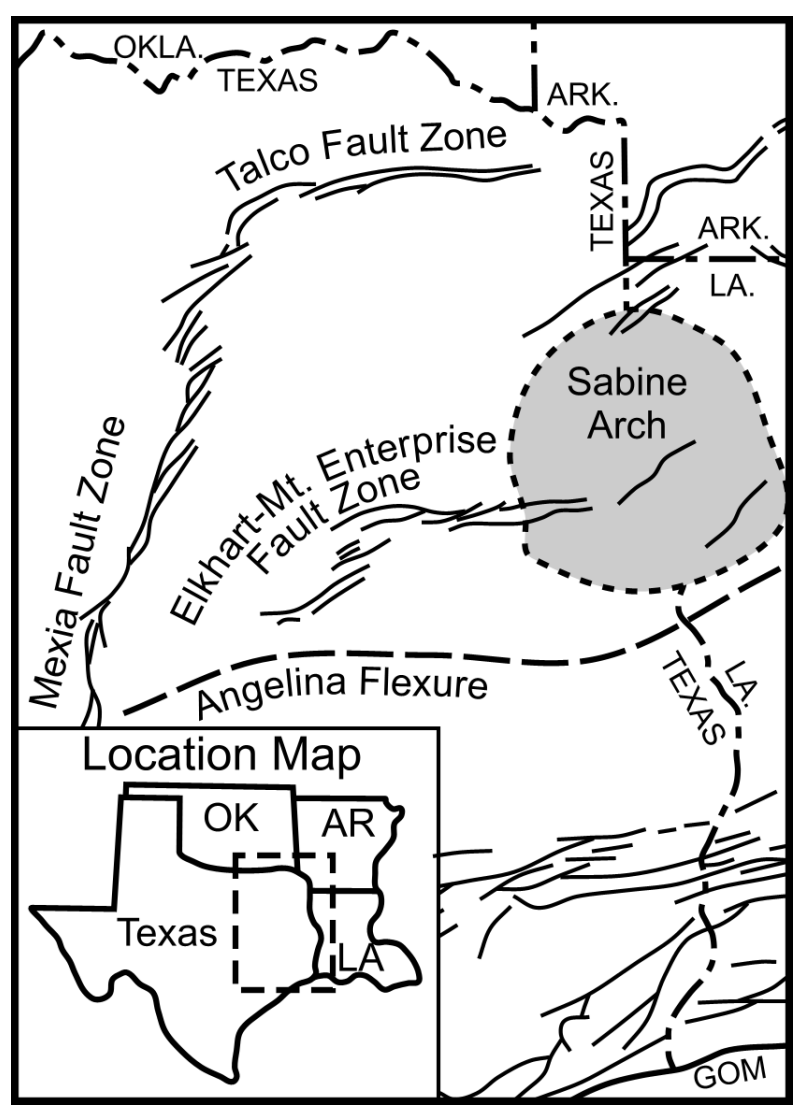

Figure 4. Simplified structural map of East Texas, including the Sabine Arch, Mexia-Talco Fault System and the Elkhart-Mt. Enterprise Fault Zone (adapted from Martin, 1978). Enlarged area shown on inset map by dashed box outline. 
meters in East Texas (Sellards et al., 1932). Although, not known for pseudokarst development in the region, the Wilcox is one of the most prolific groundwater producing units in the region with recharge occurring proximal to the Sabine Arch crest (Ashworth and Hopkins, 1995). Claiborne strata in the East Texas unconformably overlie Wilcox strata and consist of alternating and complexly interfingered coarse-grained sandstones of fluvial and littoral origin with fine-grained sandstones, siltstones and claystones of lagoonal, shallow marine and deltaic origin (Sellards et al., 1932). Generally, coarser-grained facies are more common towards the northern portion of the study area and finer-grained facies occur more abundantly to the south. Claiborne strata consist of a typical rhythmic series of continental and shallow marine facies and ranges up to $450 \mathrm{~m}$ thick. Conformably overlying the Claiborne Group, the Jackson Group consists of thin-bedded, shallow marine and beach deposits with zones of argillaceous and tuffaceous clays and tuff, which can reach total thicknesses of $90 \mathrm{~m}$ (Sellards et al., 1932).

Within East Texas, previous pseudokarst development has only been documented within the Claiborne Group and specifically within the sandstone facies that were deposited as continental sediments (Figure 3). The Claiborne Group is subdivided into the Carrizo, Recklaw, Queen City, Weches, Sparta, Cook Mountain and Yegua formations from oldest to youngest (Figure 2). Carrizo strata consist of $90 \%$ medium-grained sand and $10 \%$ sandy clay with the lower portions more heterogeneously cemented by ferruginous material (Sellards et al., 1932). Queen City deposits consist of $70 \%$ fine- to medium-grained sand, $22 \%$ sandy silty clay, $7 \%$ bentonite and glauconite clay and 1\% lignite (Sellards et al., 1932). Sparta Sandstone consists of $70 \%$ fine- to medium-grained sand, $25 \%$ sandy clay, 3\% glauconite, $1 \%$ limonite and $1 \%$ lignite (Sellards et al., 1932). The Carrizo, Queen City and Sparta sandstones were all deposited in continental to littoral environments and are known to host pseudokarst features; however, the more indurated and heterogeneously cemented Carrizo strata appear to be the most favorable for zones for pseudokarst development. Other formations within the Claiborne Group were primarily deposited in marine, littoral and lacustrine environments and reflect higher clay contents (Sellards et al., 1932) which do not appear to promote pseudokarst development in the region.

\section{East Texas Pseudokarst}

Pseudokarst development in East Texas occurs as sinkholes, springs and isolated caves in competent facies, while loose, unconsolidated sediments host numerous small suffosion features (Stafford et al., 2010). As with any environment where competent bedrock is overlain by loose unconsolidated material, suffosion features occur as both natural and anthropogenically enhanced structures. Many of these suffosion features act as macropores and fast flow paths for groundwater recharge and bypass features for migration of overland flow to local fluvial systems. True pseudokarst development does occur in the Carrizo, Queen City and Sparta sandstones; some of these features are directly associated with sinkholes, some are effectively modified bypass features and most are associated with spring discharge along permeability horizons. Cave development is limited to competent facies and occurs most commonly in variably cemented zones, where heterogeneous cementation promotes both stable cave development and mechanical disaggregation of clastic grains.

Boatman Cave Complex (Figure 5B) in northern Nacogdoches County represents typical pseudokarst development in East Texas, where a series of springs discharge from the Carrizo Sandstone at a low permeability contact. While only one of the three features at this location meets the true definition of a Texas cave (i.e. length greater than five meters), these small caves are each developed along a vertical fracture plane where laterally migrating groundwater has physically disaggregated sandstone grains near the land surface interface, resulting in three distinct springs converging and discharging into an incised valley. Each spring feature exhibits conduit-like characteristics, with the largest feature actively developing an upward stoping chimney. Most pseudokarst features in the East Texas region exhibit this typical morphology and are not associated with sinkhole development.

At a slightly larger scale, Tonkawa Springs in northern Nacogdoches County is associated with Camp Tonkawa Cave (Figure 5C) which consists of cave development along an enlarged vertical fracture in the Carrizo sandstone. The cave is primarily developed along an east-west fracture that water is discharging horizontally through; a secondary spring inlet converges in the western portion of the cave before discharging to the land surface. The cave was extensively modified when 


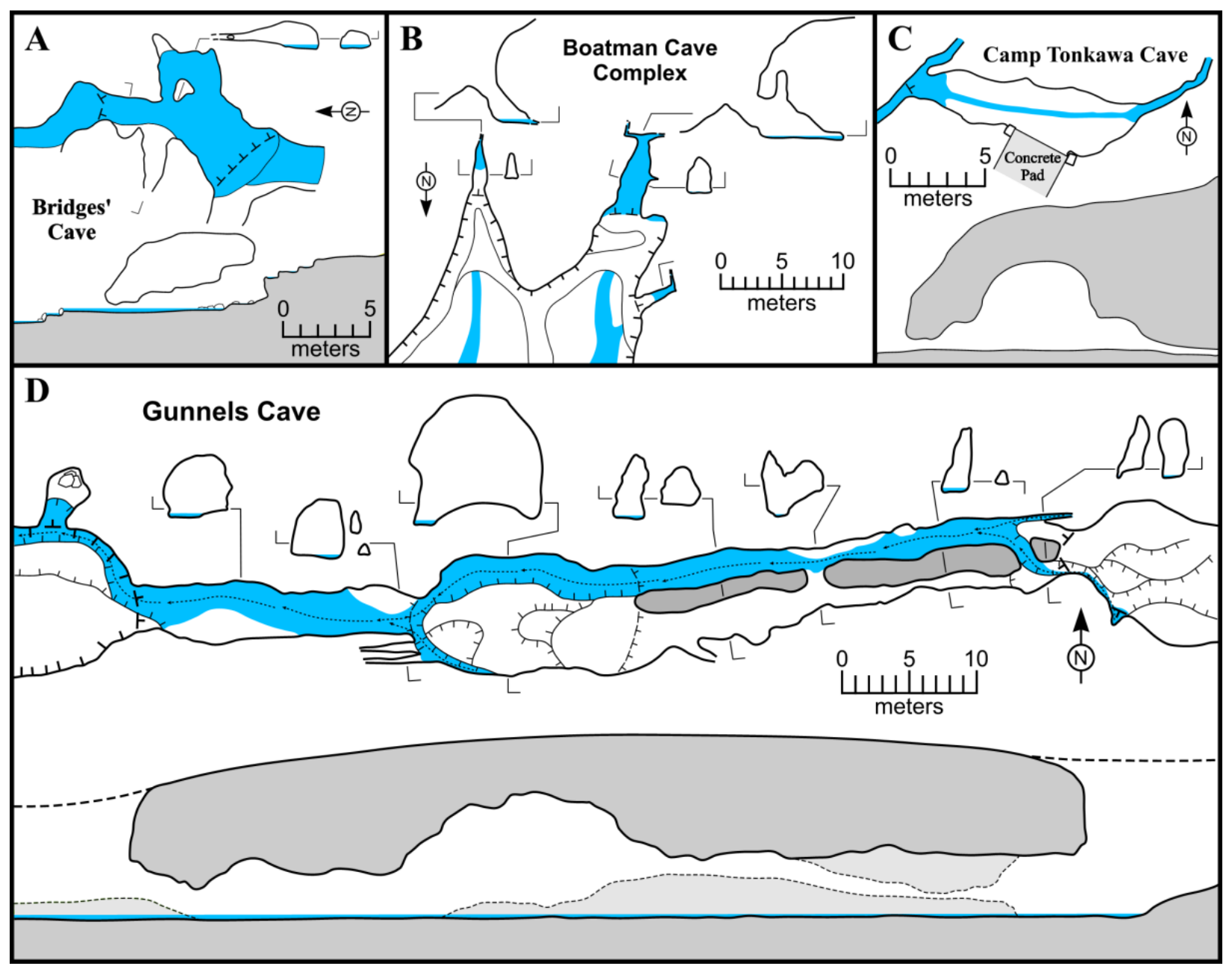

Figure 5. Simplified cave maps of representative pseudokarst caves in the study area, including (A) Bridges' Cave, (B) Boatman Cave Complex, (C) Camp Tonkawa Cave and (D) Gunnels Cave.

the spring was previously exploited for natural spring water bottling and once powered a grist mill (Brune, 1981); however, much of the original morphology can still be discerned. While some of the four meter tall cave chamber appears to be the result of upward stoping processes, much of it appears smooth and indicative of disaggregation of grains from conduit flow. It appears that most of the cave was originally formed as pressurized fluids were delivered via the fracture plain into the low pressure cavity, creating upwelling flow and producing a morphology, suggesting that the spring associated with cave formation may have an artesian component to it.

An end-member example of this same process occurs in the Carrizo Sandstone in Shelby County with the development of Gunnels Cave (Figure 5D), the largest and most extensive pseudokarst cave currently documented in the region. Gunnels Cave is approximately 70 meters long with over $160 \mathrm{~m}$ of surveyed passage and a depth of 12 meters. The cave consists of a linear passage developed along an east-west fracture with one dominant spring and two secondary springs. This suite of springs has formed a lower, northern passage and a higher, southern passage that converge into a single large chamber in the western portion of the cave. The chamber is approximately eight meters tall, almost ten meters wide and encompasses the central quarter of the cave. Throughout the cave, numerous small alcoves and ceiling structures occur suggesting a similar speleogenetic origin as Tonkawa Cave but on a much grander scale. The cave opens to the west, where spring discharge forms an incised valley with additional small alcove caves along its margins, while the eastern portion of the cave connects to a large, steep-walled sinkhole approximately $15 \mathrm{~m}$ wide and $50 \mathrm{~m}$ long that gently slopes into a watershed covering almost one hectare. 
Gunnels Cave has long been a local cultural resource, as evidenced by historical graffiti within the cave that dates from the late $19^{\text {th }}$ century.

In contrast to the pseudokarst caves described above, small bypass caves do develop in variably cemented and fractured sandstone facies. Bridges' Cave (Figure 5A) in the western portion of the study area is developed in the Sparta Sandstone where heavily hematite cemented horizons provide both permeability and structural boundaries. In Bridges' Cave, a fluvial system has breached a heavily indurated zone approximately one decimeter thick along an east-west fracture plane, enabling stream flow to descend abruptly several meters. Flow continues to traverse laterally on top of a second indurated layer, where the cave formed over a distance of approximately ten meters. Small alcoves exist within the cave, likely a result of turbulent flow conditions created during intense storm events that rapidly increased the flow through this bypass feature.

\section{GIS Analysis of East Texas Pseudokarst}

Analyses of karst terrains have been greatly aided in the past decade by improved digital resources that enable widespread characterization of large regions through GIS (Geographic Information System) techniques; however, the precision of the results are directly proportional to the quality of available data and is no replacement for physical mapping and field studies (Stafford et al., 2008). In East Texas, GIS analyses are complicated by lack of high precision data, extensive vegetation and abundant low gradient fluvial systems. Unlike other portions of the state, LiDAR (Light Detection and Ranging) data does not occur for most of East Texas, with the exception of limited data recently collected through TNRIS (Texas Natural Resource and Information System) in the proximity of the Toledo Bend Reservoir. Therefore, regional GIS analyses are limited to low resolution (10 meter) digital elevation models derived from digitized 1:24,000 quadrangle maps and color-infrared imagery; however, imagery analyses in densely forested regions has very limited application in geomorphic analyses of karst/pseudokarst features.

A sinkhole analysis was conducted on the seven counties of interest in East Texas as an assessment of the feasibility for pseudokarst delineation across the region. Closed depressions were delineated across the study area through DEM (Digital Elevation Model) analysis. A modified tenmeter DEM was created with all depressions filled based on flow accumulation analysis. This modified DEM with filled depressions was then subtracted from the original, unmodified, DEM to identify depressions. The result of DEM raster subtraction identified 2,970 individual closed depressions within the 15,146 square kilometer study area. These identified closed depressions were then filtered to remove features that had a high probability of not being actual pseudokarst features, based on similar filtering methods used in delineation of sinkholes formed by karst processes (Bryant, 2012). Closed depressions that overlapped or that occurred within ten meters of streams and rivers were removed as these features may be associated with fluvial development and do not reflect collapse or suffusion pseudokarst features; however, it is probable that this process also removed some true sinkholes as will all processes involving filtering of data. Closed depressions that intersected or occurred within ten meters of ponds, lakes and surface impoundments were removed because they represent anthropogenic closed depressions associated with development of surficial water resources. Closed depressions within ten meters of roads and highways were removed because it is probable that most of these features are the result of anthropogenic activity associated with infrastructure construction, based on initial field verification. Finally, closed depressions were filtered by surficial geology, where closed depressions within fine-grained, clastic strata (e.g. Jackson Group, Wilcox Group and the Recklaw, Weches, Cook Mountain and Yequa formations of the Claiborne Group) were removed because pseudokarst development has not been documented in these strata within the study area. After filtering to remove all closed depressions not likely to be associated with pseudokarst development, 123 probable pseudokarst sinkholes were defined in the Carrizo, Queen City and Sparta sandstones; however, these features are limited to those closed depressions that cover at least one hundred square meters because of the limitations of tenmeter DEM data. The significant reduction in number of identifiable natural sinkholes from an initially large delineation of closed depressions is consistent with studies in karst terrains where $94 \%$ of initially identified features were removed by filtering (Bryant, 2012).

Density analyses of delineated closed depressions and probable pseudokarst sinkholes indicate clustered trends of development. The highest concentrations of closed depressions occur in Wilcox strata and Quaternary alluvium in unfiltered data analyses (Figure 6), which are primarily associated with abundant meandering, 
low gradient streams and oxbow lake environs in the northeastern portion of the study area (see DEM on Figure 1), with secondary abundant densities occurring in coarser-grained facies in the western portion of the study area. Density analyses of probable pseudokarst sinkholes (Figure 7) indicate that the greatest concentrations occur within the western portion of the study area in Sparta and Queen City sandstones and in the northern portion of

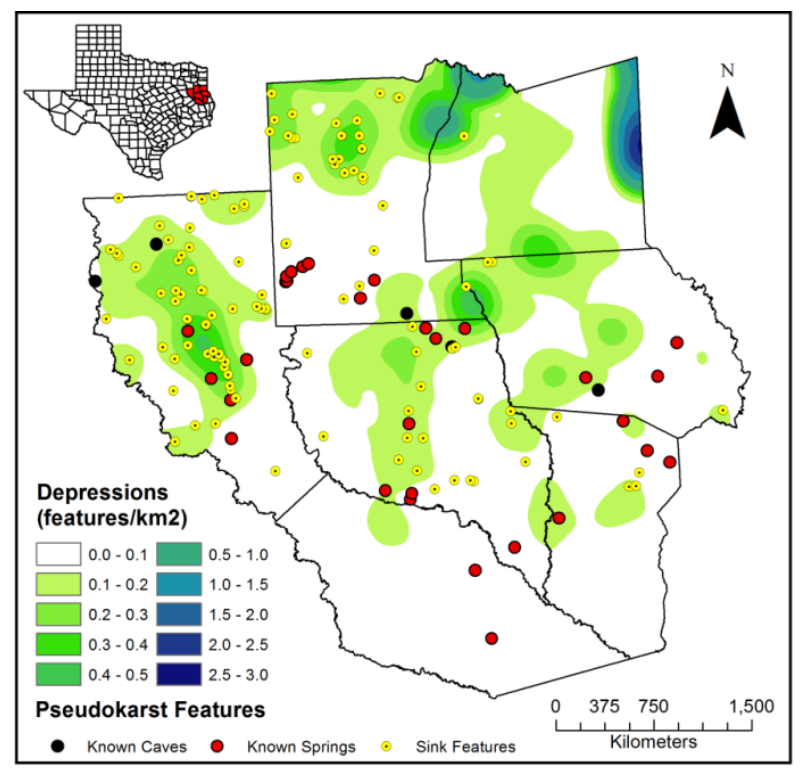

Figure 6. Closed depression density identified through DEM analyses (data from Texas Natural Resources Information System).

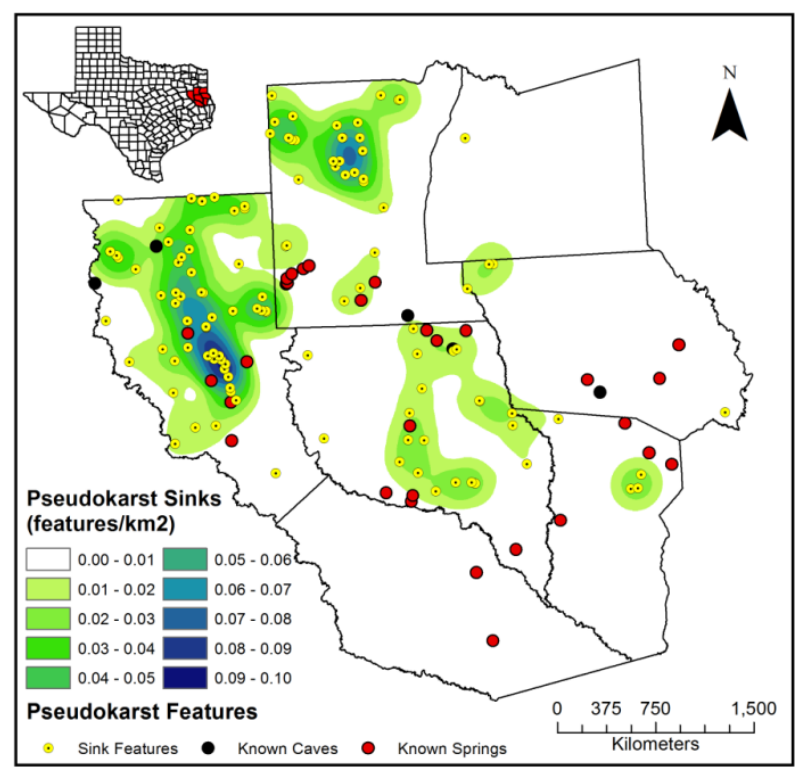

Figure 7. Probable pseudokarst sinkhole density identified through DEM analyses after filtering (data from Texas Natural Resources Information System). the study area in the Carrizo Sandstone. However, these data indicate that Gunnels Cave, the longest pseudokarst cave in East Texas, is truly a unique anomaly occurring in an extremely low sinkhole density region. While density analyses does provide indications of regions of more probable pseudokarst development, the nature of the original data creates a distinct bias that eliminates the ability to discern small-scale pseudokarst features. Low gradient fluvial systems of the area add an additional level of complexity in evaluating whether features are the result of pseudokarst development or are constructional or erosional features associated with fluvial evolution.

In addition to density analyses, slope analyses can be used to further refine probable areas of potential pseudokarst development; however, the same limitations of data apply. By calculating the slope of the ten-meter DEM, regions with high angle slopes can be defined as areas that are beyond the angle of repose for loose, unconsolidated sediments. Therefore, these regions are likely areas where collapse structures or incised valleys occur in more competent facies. By comparing regions where slopes greater than thirty degree occur with regions of high sinkhole density, better refinement of potential area of probable pseudokarst development can be delineated (Figure 8). While these high gradient regions continue to indicate the western portion of the study area likely has

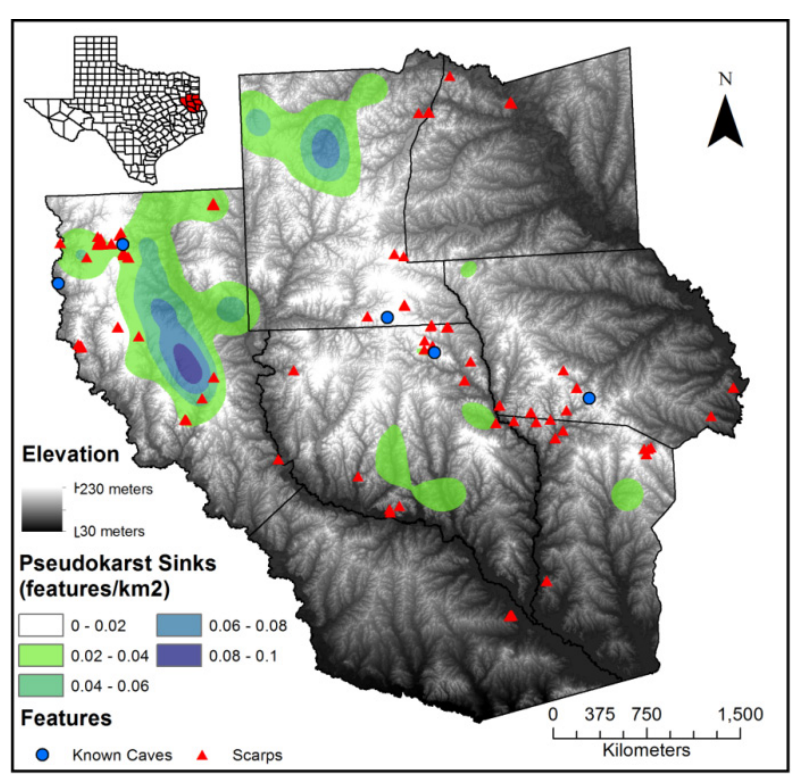

Figure 8. Comparison of steep scarps (slopes $>30$ degrees) with probably pseudokarst sinkhole density identified through DEM analyses after filtering (data from Texas Natural Resources Information System). 
the greatest pseudokarst development and warrants more field study, it also indicates that the Gunnels Cave region should be investigated in more detail. Numerous high angle slopes occur within this region which are likely associated with entrenched valleys and potential spring discharge points that may have formed pseudokarst features in the Carrizo Sandstone.

\section{Conclusion}

Pseudokarst development is limited in East Texas and primarily occurs within the coarser-grained clastics of the Claiborne Group, including the Carrizo, Queen City and Sparta sandstones. Pseudokarst features include sinkholes, springs and caves, which are largely associated with the lateral and vertical migration of aquifer fluids along fracture planes which have created preferential flow paths. Permeability boundaries between fine-grained and coarse-grained facies as well as variable ferruginous cementation primarily control the lateral development of pseudokarst caves. Most caves appear to be largely the result of lateral migration of shallow groundwater; however, speleogens in some caves suggest that an artesian component of groundwater flow is likely associated with the formation of larger pseudokarst features.

Density analyses of digital elevation models of the region indicate that pseudokarst development is most extensive in Cherokee and Rusk counties (Figure 7); however, when coupled with slope analyses to identify entrenched valleys, other trends are discernible suggesting that northern Nacogdoches, southern Shelby and northwestern San Augustine counties are also probable sites of more intense pseudokarst development (Figure 8). Although these data are promising, the limitations of ten-meter digital elevation models derived from digitized quadrangle maps presents a large sampling bias based on data quality, but these data do provide preliminary information for focusing field mapping projects to better define the range and extent of pseudokarst within the East Texas region.

Most sinkholes and collapse structures in East Texas are the result of suffusion processes; however, true pseudokarst features are common within the region. Because suffusion features are more common, they provide greater infrastructure and economic concern in the region. Leaky pipelines, poor placement of storm runoff and building construction often focus water through unconsolidated sediments throughout the region resulting in potential geohazards and significant economic loss, attesting to the need for greater public education within the region. In spring 2012, several small earthquakes, up to 4.8 in magnitude, occurred near Timpson, Texas in the study area, which were reported to have induced collapse and sinkhole formation. However, these reports appear to be associated with shallow suffusion features and were likely the result of water from leaky pipelines affected by the ground movement and are not associated with true pseudokarst development in the region.

\section{References}

Adams R. 1990. Effects of Inherited Pre-Jurassic Tectonics on the U.S. Gulf Coast. Gulf Coast Association of Geological Societies 43: 1-9

Ashworth J, Hopkins J. 1995. Aquifers of Texas. Texas Water Development Board Report 345. Austin (TX): Texas Water Development Board.

Atkinson GL. 2003. The caves and pseudokarst of East Texas. Austin (TX): Texas Speleological Survey.

Bryant AW. 2012. Geologic and Hydrogeologic Characterization of Groundwater Resources in the Fredericksburg Group, North Nolad Creek Province, Bell County, Texas. [Master's Thesis]. Nacogdoches (TX): Stephen F. Austin State University.

Brune G. 1981. Springs of Texas: Volume I. College Station (TX): Texas A\&M University Press.

Elliott WR, Veni G, editors. 1994. The caves and karst of Texas. Huntsville (AL): National Speleological Society.

Estaville LE, Earl RA. 2008. Texas water atlas. College Station (TX): Texas A\&M University Press.

Martin RG. 1978. Northern and eastern Gulf of Mexico continental margin stratigraphic and structural framework. In: Bouma AH, Moore GT, Coleman JM, editors. Framework, facies, and oil-trapping characteristics of the upper continental margin. Tulsa (OK): American Association of Petroleum Geologists, Studies in Geology 7: 21-42.

Nichols PH, Peterson GE, Wercestner CE. 1968. Summary of subsurface geology of northeast Texas. In: Beebe BW, Curtis BF, editors. Natural gases of North America. Tulsa (OK): American Association of Petroleum Geologists Memoir 9, 2: 982-1004.

Palmer AN. 2007. Cave Geology. Dayton (OH): Cave Books.

Sellards EH, Adkins WS, Plummer FB. 1932. The geology of Texas, Volume I stratigraphy, The University of Texas Bulletin No. 3232. Austin (TX): Bureau of Economic Geology. 
Shelby CA, Pieper MK, Wright AC. 1968. Palestine Sheet: Geologic Atlas of Texas. Austin (TX): Bureau of Economic Geology.

Stafford KW, Rosales-Lagarde L, Boston PJ. 2008. Castile evaporite karst potential map of the Gypsum Plain, Eddy County, New Mexico and Culberson County, Texas: A GIS methodological comparison. Journal of Cave and Karst Studies 70 (1): 35-46.

Stafford KW, Shaw MG, Brown W. 2010. Pseudokarst of East Texas: geomorphic features and evolution. Geological Society of America Abstracts with Programs 42 (2): 99.

Wermund EG. 1996. Physiographic map of Texas. Austin (TX): Bureau of Economic Geology. 
